\title{
Peningkatan Pengetahuan Peternak Ayam Kampung Super di Kabupaten Manokwari Tentang Penggunaan Nanoenkapsulasi Minyak Buah Merah (Pandanus conoideus) sebagai Fitobiotik untuk Meningkatkan Pendapatan dan Keuntungan Usaha
}

\author{
Marisabeth Theresia Hasiana Silitonga ${ }^{1 *}$, Maria Herawati ${ }^{1}$, Susan Carolina Labatar ${ }^{1}$ \\ ${ }^{1}$ Program Studi Penyuluhan Peternakan dan Kesejahteraan Hewan, Politeknik Pembangunan \\ Pertanian Manokwari \\ *Corresponding author: marisabethsil@gmail.com
}

\begin{abstract}
Abstrak
Penelitian ini bertujuan untuk mengetahui peningkatan pengetahuan peternak ayam kampung super di Manokwari tentang penggunaan nanoenkapsulasi minyak buah merah (Pandanus conoideus) sebagai fitobiotik untuk meningkatkan pendapatan dan keuntungan usaha. Sasaran penelitian adalah 20 orang anngota kelompok santri tani yang aktif tergabung dalam Kelompok Santri Tani Milenial (KSTM) di Kabupaten Manokwari. Penelitian eksperimental penggunaan nanoenkapsulasi minyak buah merah pada ayam kampung super dilaksanakan pada bulan OktoberDesember 2019, sedangkan penelitian untuk mengetahui tingkat pengetahuan peternak ayam kampung super dilaksanakan pada bulan Mei 2020 di Pesantren Darussalam, Kampung SP-3, Distrik Manokwari Barat, Kabupaten Manokwari, Provinsi Papua Barat. Metode penyuluhan yang digunakan adalah dengan pendekatan kelompok melalui ceramah, diskusi dan demonstrasi cara. Teknik evaluasi untuk mengukur pengetahuan peternak menggunakan metode pre test dan post test yang terdiri dari 20 pertanyaan. Hasil pre test dan post test menunjukan adanya perubahan peningkatan pengetahuan peternak tentang penggunaan nanoenkapsulasi minyak buah merah (Pandanus conoideus) sebagai fitobiotik untuk meningkatkan pendapatan dan keuntungan usaha dengan nilai rerata hasil pre test 40,2 dan rerata hasil post test 86,5 , artinya sebelum diberikan penyuluhan peternak termasuk dalam kategori sedang dan setelah dilakukan penyuluhan menjadi kategori tinggi.
\end{abstract}

Kata kunci: Ayam kampung super, Buah merah, Fitobiotik, Keuntungan, Pengetahuan

\begin{abstract}
This study aims to determine the increase in knowledge of super native chicken Farmer in Manokwari about the use of red fruit oil (Pandanus conoideus) nanoencapsulation as phytobiotic to increase income and business profit. The research target was 20 members of Santri Millennial Farmer Groups who are actively involved in Santri Millennial Farmer Groups in Manokwari Regency. Experimental research on the use of red fruit oil nanoencapsulation in super native chickens was carried out in October-December 2019, while research to determine the level of knowledge of super native chicken farmer was carried out in May 2020 at Pesantren Darussalam, Kampung SP-3, West Manokwari District, Manokwari Regency, Papua Province. The extension method used is a group approach through lectures, discussions and demonstrations. The evaluation technique for measuring farmer knowledge used the pre-test and post-test methods which consisted of 20 questions. The results of the pre-test and post-test showed that there was a change in the increase in farmers' knowledge about the use of red fruit oil (Pandanus conoideus) nanoencapsulation as a phytobiotic to increase income and business profits with a mean value of pre-test result of 40.2 and a mean of post-test result of 86.5, meaning before given counseling, farmers are include in the medium category and after given counseling are in the high category.
\end{abstract}

Keywords: Super native chicken, Red fruit, Phytobiotic, Profit, Knowledge 
Prosiding Seminar Nasional Pembangunan dan Pendidikan Vokasi Pertanian

Politeknik Pembangunan Pertanian Manokwari, 14 November 2020

e ISSN : 2774-1982

\section{PENDAHULUAN}

Buah merah adalah salah satu tanaman obat asli Indonesia yang berasal dari Papua, seperti Papua New Guinea dan Provinsi Papua (Rohman dan Windarsih, 2018) dan telah dikenal luas memiliki banyak manfaat untuk kesehatan karena mengandung zatzat alami yang dapat meningkatkan kekebalan tubuh dan mempertahankan status kesehatan manusia. Zat aktif yang terkandung dalam buah merah diantaranya tokoferol (vitamin E), alfatokoferol dan betakaroten berfungsi sebagai antioksidan yang mampu menangkal radikal bebas dan meningkatkan kekebalan tubuh (Budi dan Paimin, 2005). Fitobiotik pada unggas dapat meningkatkan pertumbuhan dan efisiensi pakan, meningkatkan daya tahan tubuh unggas (Hosseini dkk, 2016). Kekurangan dari penggunaan fitobiotik tersebut sebagai feed additive, yaitu kelarutannya yang rendah, cepat terdegradasi, penyebarannya kurang merata, bioavailabilitasnya rendah, dan cepat rusak oleh pengaruh lingkungan dalam sistem pencernaan (Esfanjani dan Fajri, 2016). Usaha yang dapat dilakukan untuk mengatasi beberapa kekurangan tersebut adalah dengan pembuatan nanoenkapsulasi. Ukuran partikel yang kecil membuat produk nanoenkapsulasi dapat dengan mudah diserap oleh sistem pencernaan ternak. Salah satu contoh dari produk nanoenkapsulasi adalah nano mineral yang memiliki kemampuan untuk masuk ke dalam usus halus kemudian dengan mudah akan mengikuti darah dan menyebar ke organ target (Swain dkk, 2016).

Ayam kampung merupakan salah satu jenis unggas yang penyebarannya hampir merata di seluruh Indonesia. Pemeliharaan ayam kampung cukup mudah, tidak membutuhkan tempat yang luas dan penyediaan pakan yang murah (Yaman, 2010). Ternak ayam kampung super adalah hasil persilangan ayam sehingga diperoleh pertumbuhan yang cepat, namun tekstur dan cita rasa layaknya ayam kampung (Suryanto dan Kurniawan, 2018)

Nanoenkapsulasi dapat dibuat dengan menggunakan beberapa metode tergantung jenis dan sifat senyawa bioaktif yang akan digunakan. Salah satu metode yang dapat dilakukan untuk pembuatan nanoenkapsulasi senyawa bioaktif buah merah adalah nanoenkapsulasi dengan gelasi ionik. Prinsip pembuatan nanoenkapsulasi dengan metode ini adalah terjadinya interaksi ionik antara gugus amin pada kitosan yang bermuatan positif dengan polianion yang bermuatan negatif yaitu Sodium Tripolyphosphate (STPP) (Sundari dkk, 2014). Penambahan nanoenkapsulasi minyak buah merah diharapkan dapat meningkatkan produktivitas ayam kampung super sehingga dapat menambah pendapatan dan keuntungan peternak. 
Prosiding Seminar Nasional Pembangunan dan Pendidikan Vokasi Pertanian Politeknik Pembangunan Pertanian Manokwari, 14 November 2020

e ISSN : 2774-1982

Pondok Pesantren Darussalam di Kampung SP-3, Distrik Manokwari Barat, Kabupaten Manokwari, Provinsi Papua Barat sejak tahun 2019 terlibat dalam program Kelompok Santri Tani Milenial (KSTM) yang bergerak pada usaha budidaya ayam kampung super dengan jumlah populasi ternak berjumlah 325 ekor. Selama ini, peternak santri milenial menggunakan jamu tradisional untuk menjaga status kesehatan ternaknya, sehingga adanya penyuluhan tentang penggunaan nanoenkapsulasi minyak buah merah sebagai fitobiotik dapat menjadi referensi bagi peternak milenial untuk meningkatkan pendapatan dan keuntungan usaha budidaya ayam kampung super.

\section{METODE}

\section{Lokasi dan Waktu Penelitian}

Penelitian eksperimental penggunaan nanoenkapsulasi minyak buah merah pada ayam kampung super telah dilaksanakan selama 60 hari terhitung dari tanggal 5 Oktober sampai dengan 5 Desember 2019 di Kampus Politeknik Pembangunan Pertanian (Polbangtan) Manokwari Provinsi Papua Barat, sedangkan penelitian untuk mengetahui tingkat pengetahuan peternak ayam kampung super dilaksanakan pada tanggal 15 Mei 2020 yang berlokasi di KSTM (Kelompok Santri Tani Milenial) Darussalam, Kampung SP-3, Distrik Prafi, Kabupaten Manokwari, Provinsi Papua Barat.

\section{Penyuluhan}

Sasaran penyuluhan adalah 20 orang anggota kelompok santri tani yang aktif tergabung dalam Kelompok Santri Tani Milenial (KSTM) di Distrik Prafi, Kabupaten Manokwari, Provinsi Papua Barat. Tujuan penyuluhan ini adalah untuk mengetahui peningkatan pengetahuan peternak ayam kampung super tentang penggunaan nanoenkapsulasi minyak buah merah (Pandanus conoideus) sebagai fitobiotik untuk meningkatkan pendapatan usaha. Media penyuluhan yang digunakan dalam kegiatan penyuluhan adalah folder, untuk metode penyuluhan yang digunakan yaitu dengan pendekatan kelompok melalui ceramah dan diskusi dengan peternak kemudian demonstrasi cara pembuatan nanoenkapsulasi minyak buah merah untuk ayam kampung super.

Proses nanoenkapsulasi yaitu menggunakan metode gelasi ionik dengan mencampurkan 2\% ekstrak ampas buah merah (hasil ekstrak buah merah dengan 96\% etanol): $0,625 \%$ kitosan (kitosan yang telah dilarutkan dalam 2,50\% asam asetat, kemudian diaduk dengan menggunakan blender selama 2 menit): 0,75\% STPP (yaitu $0,75 \%$ STPP yang telah dilarutkan dengan aquades dan diaduk menggunakan blender 
Prosiding Seminar Nasional Pembangunan dan Pendidikan Vokasi Pertanian

Politeknik Pembangunan Pertanian Manokwari, 14 November 2020

e ISSN : 2774-1982

selama 2 menit). Perbandingan larutan nanoenkapsulasi sebagai fitobiotik yaitu ekstrak ampas buah merah, kitosan dan STPP $(0,81: 0,16: 0,03)$ (Sundari, dkk 2014; Syaefullah et al., 2019; Timur et al., 2020).

\section{Evaluasi Penyuluhan}

Evaluasi dilakukan untuk mengetahui tingkat pengetahuan peternak dengan mengukur kemampuan peternak sebelum pelaksanaan penyuluhan (pre-test) dan setelah kegiatan penyuluhan (post-test). Metode pre-test dan post-test merupakan alat penilaian yang sangat dianjurkan untuk mengukur keberhasilan kemajuan suatu proses pembelajaran karena evaluasinya bersifat ringkas dan efektif (Costa, 2013). Secara umum teknik pemberian skor yang digunakan dalam penyuluhan ini adalah skala likert. Skala likert digunakan untuk mengukur sikap dan pengetahuan seseorang atau kelompok tentang fenomena sosial (Riduwan, 2010). Pertanyaan untuk mengukur nilai tingkat pengetahuan dalam bentuk kuesioner sebanyak 10 soal dengan skor sebagai berikut:

Menjawab tidak $\quad: 0$

Menjawab ya $: 5$

Menjawab ya dan menjelaskan : 10

Nilai dari masing-masing komponen dirumuskan sebagai berikut:

Nilai tertinggi : $10 \times 10=100$

Nilai terendah $: 10 \times 0=0$

Interval : $\frac{100-0}{3}=33,3$

dengan kategori:

$66,8-100=$ tinggi

$33,4-66,7=$ sedang

$0-33,3=$ rendah

\section{HASIL DAN PEMBAHASAN}

\section{Profil Pondok Pesantren Darussalam}

Pondok Pesantren Darussalam terletak di Jl. Gunung Semeru Jalur 3 Kampung Aimasi Distrik Prafi Kabupaten Manokwari dengan luas lahan 4 Ha. Pondok Pesantren Darussalam saat ini telah berkembang sebagai salah satu sentral pendidikan Agama Islam di Kabupaten Manokwari dengan proses pembelajaran menggunakan sistem klasikal, sorogan, bandongan, mukhafadzoh, takror, syawir. Selain itu juga diadakan bimbingan 
Prosiding Seminar Nasional Pembangunan dan Pendidikan Vokasi Pertanian

Politeknik Pembangunan Pertanian Manokwari, 14 November 2020

e ISSN : 2774-1982

untuk keterampilan dan kesenian, bahasa, pertanian, perkebunan, peternakan. Pondok Pesantren Darussalam terbagi oleh beberapa jenjang pendidikan, yaitu SD, SMP, SMA dengan jumlah santri 119 orang. Santri Pondok Pesantren Darussalam juga terlibat program dari Kementerian Pertanian tahun 2019 yaitu KSTM (Kelompok Santri Ternak Millenial) yang juga didampingi oleh pengurus pondok dengan memberikan bantuan 500 ekor ayam kampung super, pakan, dan obat-obatan. Saat ini jumlah ternak ayam kampung super yang masih dipelihara di KSTM Darussalam berjumlah 325 ekor.

Tipe kandang yang digunakan oleh peternak di KSTM (Kelompok Santri Ternak Milenial) Darussalam yaitu kandang baterai dan liter. Kandang baterai digunakan untuk ayam yang berumur 0-30 hari. Setelah umur 30 hari, ayam dipindahkan ke kandang litter dengan sekam sebagai alas kandangnya. Pakan yang digunakan yaitu pakan pabrik, yang dicampur dengan limbah dapur seperti sayuran, ampas nasi dan limbah yang mudah di cerna oleh ayam. Untuk minumannya menggunakan air dan peternak membuat jamu yang terbuat dari buah mengkudu. Sebelum menggunakan jamu tradisonal, peternak mencampurkan air minum dengan vitamin yang biasa di jual di toko.

Untuk kondisi usaha di KSTM ayam yang siap dijual berusia 3 bulan, dengan harga Rp.90.000/ekor dengan rata-rata bobot ayam $2 \mathrm{~kg}$, serta ayam yang berumur 1 bulan untuk dijadikan bibit dengan harga Rp.50.000/ekor.

\section{Pendapatan dan Keuntungan Usaha Penggunaan Minyak Buah Merah (Pandanus conoideus) Sebagai Fitobiotik Pada Ternak Ayam Kampung Super}

Penelitian pada ternak ayam kampung super yang diberikan nanoenkapsulasi minyak buah merah (Pandanus conoideus) terhadap pendapatan dan keuntungan usaha tertera pada Tabel 1 .

Tabel 1 memperlihatkan bahwa, biaya penggunaan fitobiotik yang paling tinggi yaitu pada perlakuan P1 (air minum $+2,5 \%$ ekstrak minyak buah merah), sedangkan yang terendah yaitu pada perlakuan P2 (air minum $+2,5 \%$ nanoenkapsulasi minyak buah merah). Pendapatan tertinggi diperoleh pada perlakuan P2 (Rp.385.497,40), sedangkan yang terendah ada pada perlakuan P1(Rp.-1.019.899,05). Keuntungan diperoleh dari pendapatan dikurangi dengan biaya yang tidak diperhitungkan yaitu tenaga kerja. Dari perhitungan tersebut diperoleh hasil bahwa, keuntungan yang tertinggi diperoleh pada perlakuan P2 (Rp.375.497,40), sedangkan yang mengalami kerugian ada pada perlakuan P1 (Rp.-1.029.899,05). Hal ini menunjukkan bahwa, pendapatan dan keuntungan yang paling tinggi diperoleh pada perlakuan P2 (air minum $+2,5 \%$ nanoenkapsulasi minyak buah merah). 
Prosiding Seminar Nasional Pembangunan dan Pendidikan Vokasi Pertanian Politeknik Pembangunan Pertanian Manokwari, 14 November 2020

e ISSN : 2774-1982

Tabel 1. Pendapatan dan Keuntungan Usaha Penggunaan Minyak Buah Merah Sebagai Fitobiotik Pada Ternak Ayam Kampung Super

\begin{tabular}{|c|c|c|c|c|c|}
\hline URAIAN & P0 & P1 & $\mathbf{P 2}$ & P3 & P4 \\
\hline $\begin{array}{l}\text { Biaya-biaya } \\
\text { Penyusutan kandang } \\
(\mathrm{Rp})\end{array}$ & 20.000 & 20.000 & 20.000 & 20.000 & 20.000 \\
\hline Penyusutan alat (Rp) & 8.800 & 8.800 & 8.800 & 8.800 & 8.800 \\
\hline Listrik & 20.000 & 20.000 & 20.000 & 20.000 & 20.000 \\
\hline DOC (Rp) & 300.000 & 300.000 & 300.000 & 300.000 & 300.000 \\
\hline Pakan (Rp) & $259.536,73$ & $261.099,05$ & $343.677,60$ & $346.376,69$ & $291.722,76$ \\
\hline Fitobiotik (Rp) & 0 & 1.250 .000 & 92.025 & 161.800 & 323.600 \\
\hline Total (Rp) & $608.336,73$ & 1.859.899,05 & $784.502,60$ & $856.976,69$ & $964.122,76$ \\
\hline \multicolumn{6}{|l|}{ Pendapatan } \\
\hline Ayam terjual (ekor) & 13 & 14 & 18 & 19 & 15 \\
\hline Harga per ekor (Rp) & 70.000 & 60.000 & 65.000 & 60.000 & 65.000 \\
\hline Penerimaan (Rp) & 910.000 & 840.000 & 1.170 .000 & 1.140 .000 & 975.000 \\
\hline Pendapatan (Rp) & $301.663,27$ & $-1.019 .899,05$ & $385.497,40$ & 283.023,31 & $10.877,24$ \\
\hline \multicolumn{6}{|l|}{ Keuntungan } \\
\hline Biaya tenaga kerja (Rp) & 10.000 & 10.000 & 10.000 & 10.000 & 10.000 \\
\hline Keuntungan (Rp) & $291.663,27$ & $-1.029 .899,05$ & $\mathbf{3 7 5 . 4 9 7 , 4 0}$ & 273.023,31 & 877,24 \\
\hline Penerimaan (Rp) & 910.000 & 840.000 & 1.170 .000 & 1.140 .000 & 975.000 \\
\hline Total Biaya (Rp) & $618.336,73$ & $1.869 .899,05$ & $794.502,60$ & $866.976,69$ & $974.122,76$ \\
\hline $\mathbf{R} / \mathbf{C}$ & 1,472 & 0,449 & 1,473 & 1,315 & 1,001 \\
\hline
\end{tabular}

Sumber: Analisis Data Primer

Keterangan:

P0 = air minum tanpa aditif (kontrol negatif)

$\mathrm{P} 1=$ air minum $+2,5 \%$ ekstrak minyak buah merah

$\mathrm{P} 2=$ air minum $+2,5 \%$ nanoenkapsulasi minyak buah merah

$\mathrm{P} 3=$ air minum $+5 \%$ nanoenkapsulasi minyak buah merah

$\mathrm{P} 4=$ air minum $+10 \%$ nanoenkapsulasi minyak buah merah

Hasil analisis pendapatan dan keuntungan (Tabel 1.) memperlihatkan bahwa penggunaan nanoenkapsulasi minyak buah merah mampu menekan angka kematian ternak sehingga ternak dapat lebih banyak terjual dan meningkatkan pendapatan dan keuntungan dibandingkan yang tidak menggunakan nanoenkapsulasi minyak buah merah (P0), hasil ini sesuai dengan penelitian Herawati et al., (2020).

\section{Peningkatan Pengetahuan Peternak Ayam Kampung Super}


Prosiding Seminar Nasional Pembangunan dan Pendidikan Vokasi Pertanian Politeknik Pembangunan Pertanian Manokwari, 14 November 2020

e ISSN : 2774-1982

Pre-test diberikan kepada responden yaitu santri tani milenial pada saat sebelum penyuluhan sedangkan post-test diberikan kepada responden untuk mengukur sejauh mana peningkatan pemahaman responden setelah menerima materi penyuluhan. Data hasil pre-test dan pos-test kemudian diolah untuk mendapatkan nilai rata-rata kenaikan tingkat pengetahuan responden. Berikut adalah tabel rerata nilai pre-test dan post-test (Tabel 2).

Tabel 2. Rerata pre-test dan post-test

\begin{tabular}{clcc}
\hline No. & Kuisoner & Jumlah & Rerata \\
\hline 1 & Pre-test & 805 & 40,2 \\
2 & Post-test & 1.730 & 86,5 \\
\hline
\end{tabular}

Hasil evaluasi penyuluhan yaitu pre-test dan post-test dapat dilihat bahwa terjadi peningkatan pengetahuan responden, terlihat pada responden yang diberikan tes awal mendapatkan kategori sedang dengan rerata nilai 40,2 dan diberikan tes akhir mendapatkan kategori tinggi dengan rerata nilai 86,5 . Hal ini dikarenakan penyuluhan pada dasarnya adalah upaya perubahan berencana yang dilakukan melalui sistem pendidikan non formal dengan tujuan merubah perilaku (sikap, pengetahuan, keterampilan) sasaran untuk dapat memecahkan masalah yang dihadapinya, sehingga kualitas kehidupannya menjadi meningkat (Yunasaf, 2003). Dalam kegiatan penyuluhan ini metode yang digunakan yaitu metode pendekat kelompok, contohnya melalui diskusi kelompok dan temu 15 karya, kursus tani, demonstrasi cara atau hasil karyawisata atau widyawisata, dan lain-lain.

\section{KESIMPULAN DAN SARAN}

Berdasarkan hasil penelitian yang dilakukan pada ternak ayam kampung super disimpulkan bahwa penambahan nanoenkapsulasi minyak buah merah sebagai fitobiotik dapat meningkatkan pendapatan dan keuntungan usaha. Pendapatan dan keuntungan usaha paling tinggi ada pada perlakuan P2 (air minum $+2,5 \%$ nanoenkapsulasi minyak buah merah). Hasil pre test dan post test menunjukan adanya perubahan peningkatan pengetahuan peternak tentang penggunaan nanoenkapsulasi minyak buah merah (Pandanus conoideus) sebagai fitobiotik untuk meningkatkan pendapatan dan keuntungan usaha dengan nilai rerata hasil pre test 40,2 dan rerata hasil post test 86,5 , artinya sebelum diberikan penyuluhan peternak termasuk dalam kategori sedang dan setelah dilakukan penyuluhan menjadi kategori tinggi. Disarankan dalam penelitian ini 
Prosiding Seminar Nasional Pembangunan dan Pendidikan Vokasi Pertanian

Politeknik Pembangunan Pertanian Manokwari, 14 November 2020

e ISSN : 2774-1982

penggunaan fitobiotik selain untuk ayam kampung super perlu adanya penelitian lebih lanjut terkait dengan jenis unggas lainnya.

\section{DAFTAR PUSTAKA}

Budi, I.M. \& Paimin, F.R. (2005). Buah Merah. Jakarta: Penebar Swadaya.

Costa, M. (2013). Choosing the Right Assesment ethod: Pre-Tes/Post-Test Evaluation, Boston University, Cabrillo Colleges SLO Websites

Esfanjani, A.F. \& S.M. Jafri. (2016). Biopolymer Nano-particles and Natural Nanocarriers for Nano-encapsulation of Phenolic Compounds. Colloids and Surfaces B: Biointerfaces. 146: 532-543.

Herawati, M., Syaefullah, B. L., \& Timur, N. P. V. T. (2020). Efisiensi Ekonomi Pemeliharaan Ayam Kampung Super yang Diberi Fitobiotik dengan Teknologi Nanoenkapsulasi Minyak Buah Merah (Pandanus conoideus). Wahana Peternakan, 4(2).

Hosseini, S., M. Chamani, A. Seidavi, A.A. Sadeghi, \& Z. Pirsareai. (2016). Effect on Feeding Thymolina Powder in The Carcass Characteristics and Morphology of Small Intestine of Ross 308 Broiler Chickens. Jurnal Veteriner. 17: 615-621.

Riduwan. 2010. Skala Pengukuran Variabel-Variabel Penelitian. Bandung : Alfabet

Rohman, A., \& Windarsih, A. (2018). Characterization, Biological Activities, and Authentication of Red Fruit (Pandanus conoideus Lam) Oil. Food Research. 2(2): 134-138.

Sundari, Zuprizal, \& R. Martien. (2014). The Effect Nanocapsule of Turmeric Extracts in Rations on Nutrient Digestibility of Broiler Chickens. Animal Production. 16: 107113.

Suryanto, T \& R. Kurniawan. (2018). Ayam Kampung Joper Panen 60 hari. Jakarta: Penebar Swadaya.

Swain, P.S., S.B.N. Rao, D. Rajendran, G. Dominic \& S. Selvaraju. (2016). Nanozinc, An Alternative to Conventional Zinc as Animal Feed Supplement: A Review. Animal Nutrition. 2: 134-141.

Syaefullah, B. L., Herawati, M., Timur, N. P. V. T., Bachtiar, E. E., \& Maulana, F. (2019). INCOME OVER FEED COST PADA AYAM KAMPUNG YANG DIBERI NANOENKAPSULASI MINYAK BUAH MERAH (Pandanus conoideus) VIA WATER INTAKE. Jurnal Triton, 10(2), 54-61.

Timur, V., Herawati, M., Syaefullah, B. L., \& Bachtiar, E. (2020). Mortalitas dan Profil Organ Dalam Ayam Kampung yang diberi Fitobiotik Nanoenkapsulasi Minyak Buah Merah (Pandanus conoideus). Jurnal Triton, 11(1), 16-23. 
Prosiding Seminar Nasional Pembangunan dan Pendidikan Vokasi Pertanian

Politeknik Pembangunan Pertanian Manokwari, 14 November 2020

e ISSN : 2774-1982

Yaman, M. Aman. (2010). Ayam Kampung Unggul 6 Minggu Panen. Jakarta: Penebar Swadaya. 